\title{
ПРВ НАТПРЕВАР ПО ХЕМИЈА ЗА УЧЕНИЦИ ОД ОСНОВНИТЕ УЧИЛИШТА ОД РЕПУБЛИКА МАКЕДОНИЈА
}

Секцијата за хемиско образование при Сојузот на хемичарите и технолозите на Македонија во април 2016 година доби акредитација од МOH за организација на натпревари по хемија за ученици од основните училишта од Република Македонија.

Правилата за учество на овој натпревар се дефинирани со посебен Правилник за организација и реализација на натпревари по хемија за учениците од основното образование.

Натпреварите за учениците се организираат и одржуваат во две категории:

Категорија 1 - според наставната програма по хемија за VIII одделение.

Категорија 2 - според наставната програма по хемија за IX одделение.

Регионалните натпревари се одржаа на 14 мај 2016 год. (сабота), по претходно одржани училишни/општински натпревари, односно соодветна селекција на учениците од страна на нивните наставници. Регионалните натпревари по хемија за учениците од основното образование се одржаа во следниве училишта:

- Регион 1: ООУ „Коле Неделковски“, Скопје (координатор Славица Алексовска).

- Регион 2: ООУ „Христијан Карпош“, Куманово (координатор Ивана Димовска Нојковска).

- Регион 3: ООУ „Св. Климент Охридски“, Охрид (координатор Дивна Стрезоска).

- Регион 4: ООУ „Јосип Броз Тито“, Валандово (координатор Габриела Николова).

- Регион 5: ООУ „Гоце Делчев“, Прилеп (координатор Кети Ивановска).

- Регион 6: ООУ „Никола Карев“, Радовиш (координатор Тања Николовска).

Државниот натпревар се одржа на 28.05.2016 год. (сабота) во Институтот за хемија при ПМФ, Скопје. Според Правилникот за организација и реализација на натпревари по хемија за учениците од основното образование, како награда на најдобро пласираните натпреварувачи на државниот натпревар во секоја категорија, СXТМ доделува дипломи, според следниве критериуми:

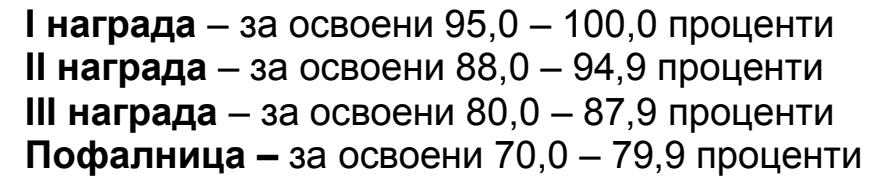

Учениците кои освоија прва награда беа наградени со книги (подарок од издавачката куќa Арс Ламина), прворангираните ученици - со подарок од Институтот за хемија, а на сите ученици на државниот натпревар СХТМ им подари маици.

Во организација и реализација на овие натпревари беа вклучени повеќе наставници од Институтот за хемија, меѓу кои проф. д-р Марина Стефова (раководител на Секцијата за хемиско образование), доц. д-р Марина Стојановска (координатор на натпреварите по хемија за ученици од основното образование), проф. д-р Владимир Петрушевски, доц. д-р Јасмина Петреска Станоева, доц. д-р Наташа Ристовска, профр. д-р Јане Богданов, проф. д-р Слоботка Алексовска, доц. д-р Сандра Димитровска-Лазова, доц. д-р Миха Буклески, м-р Милена Колевска, Игор Мавромихаилов, проф. д-р Петре Макрески, проф. д-р Љупчо Пејов, профр. д-р Билјана Пејова, проф. д-р Владимир Ивановски, Зулјета Фетаовска, Мазес Мемед, Марија Георгиевска, Дијана Симиќ, Емилија Јанкуловска, Наташа Дупкарова, Сара Глигороска, Зорица Георгиева, Митко Стефановски и Бранко Велевски. Во натпреварите беше вклучена и Иванка Мијиќ, советник по хемија од Бирото за развој на образованието, чија помош беше многу значајна за успешно одвивање на натпреварите. 
Според максимално постигнатиот број бодови во соодветната категорија, наградени беа вкупно 44 ученици.

Учениците од VIII одделенија освоија осум први, осум втори и деветнаесет трети награди и тоа:

\begin{tabular}{|c|c|c|c|}
\hline $\begin{array}{l}\text { Награ- } \\
\text { да }\end{array}$ & Име и презиме & Училиште, општина & Ментор \\
\hline I & Борјан Кочковски & ООУ „Владо Тасевски“, Карпош & Сузана Стојанова \\
\hline I & Ана Марија Наумовска & ООУ „Даме Груев“, Битола & Билјана Љубенска \\
\hline I & Делфина Апостолоска & ООУ „Гоце Делчев“, Прилеп & Кети Иваноска \\
\hline I & Мартин Кировски & ООУ „Ванчо Прке“, Штип & Ели Трајчева \\
\hline I & Владимир Шарковски & ООУ „Александар Македонски“, Аеродром & Љупка Лесовска \\
\hline 1 & Елена Василеска & ООУ „Гоце Делчев“, Демир Хисар & Никола Најдовски \\
\hline I & Леонид Сајков & ООУ „Стив Наумов“, Битола & Елица Лазаров \\
\hline I & Сара Стојанова & ООУ „Крсте Петков Мисирков“, Радовиш & Зорка Христова Трајкова \\
\hline II & Дана Доневска & ООУ „Димо Хаџи Димов“, Карпош & Виолета Димитриева \\
\hline II & Ѓоко Бојковски & ООУ „Димо Хаџи Димов“, Карпош & Виолета Димитриева \\
\hline II & Стефранија Секулоска & ООУ „Кочо Рацин“, Прилеп & Катерина Слабакоска \\
\hline II & Берна Асанова & ООУ „Крсте Петков Мисирков“, Радовиш & Зорка Христова Трајкова \\
\hline II & Иван Попјанев & ООУ „Коле Неделковски“, Центар & Славица Алексова \\
\hline II & Христијан Левкоски & ООУ „Единство - Башкими - Бирлик“, Гостивар & Весна Ролевска \\
\hline II & Бојана Кузманоска & ООУ „Гоце Делчев“, Прилеп & Кети Иваноска \\
\hline II & Јована Ваневска & ООУ „Александар Македонски“, Аеродром & Љупка Лесовска \\
\hline III & Елена Стаменковска & ООУ „Дедо Иљо Малешевски“, Берово & Сузана Гашчеовска \\
\hline III & Мартин Ангелевски & ООУ „Гоце Делчев“, Демир Хисар & Никола Најдовски \\
\hline III & Стеваноска Ирина & ООУ „Блаже Конески“, Прилеп & $\begin{array}{l}\text { Павлина Темелкоска } \\
\text { Ристеска }\end{array}$ \\
\hline III & Стојкоски Михаил & ООУ „Блаже Конески“, Прилеп & $\begin{array}{l}\text { Павлина Темелкоска } \\
\text { Ристеска }\end{array}$ \\
\hline III & Даријан Шекеров & ООУ „11 Октомври“, Центар & Марија Апостолова \\
\hline III & Драган Андреевски & ООУ „Димката Ангелов - Габерот“, Кавадарци & Даница Пецова \\
\hline III & Ивана Куновска & ООУ „Св. Кирил и Методиј“, Битола & Наталија Аспров \\
\hline III & Клаудија Кондовска & ООУ „Гоце Делчев“, Демир Хисар & Никола Најдовски \\
\hline III & Андреј Шекеров & ООУ „11 Октомври“, Центар & Марија Апостолова \\
\hline III & Бојан Ристов & ООУ „Крсте Петков Мисирков“, Радовиш & Зорка Христова Трајкова \\
\hline III & Верче Атанасова & ООУ „Крсте Петков Мисирков“, Радовиш & Зорка Христова Трајкова \\
\hline III & Дина Геговска & ООУ „Коле Неделковски“, Центар & Славица Алексова \\
\hline III & Диелза Заими & ООУ „Истикбал“, Тетово & Зија Адеми \\
\hline III & Софрија Китановска & ООУ „Јоаким Крчовски“, Крива Паланка & Дане Ангеловски \\
\hline III & Балканска Деа & ООУ „Страшо Пинџур“, Неготино & Велика Маркова \\
\hline III & Димитар Србиноски & ООУ „Д-р Владимир Полежиноски“, Кичево & Славе Ѓинковски \\
\hline III & Марија Костадинова & ООУ „Страшо Пинџур“, Неготино & Велика Маркова \\
\hline III & Методи Наумовски & ООУ „Јохан Хајнрих Песталоци“, Центар & Славица Алексова \\
\hline III & Мила Саздова & ООУ „Х.Т.Карпош“, Карпош & Даниела Радевска \\
\hline
\end{tabular}


Учениците од IX одделение освоија една прва, четири втори и четири трети награди, и тоа:

\begin{tabular}{clll}
\hline Награда & Име и презиме & Училиште, општина & Ментор \\
\hline I & Стеван Богданов & ООУ „Никола Карев“, Кочани & Весна Богданова - Василева \\
\hline II & Андреј Јанков & ООУ „Коле Неделковски“, Центар & Славица Алексова \\
\hline II & Ева Миленкова & ООУ „Кирил и Методиј“, Свети Николе & Мирјана Наунова \\
\hline II & Ана Ефтимова & ООУ „Димитар Влахов“, Штип & Славица Ефтимова \\
\hline II & Стесан Марковски & ООУ „Горгија Пулевски“, Аеродром & Фотинула Димчевска \\
\hline III & Душан Мерџановси & ООУ „Х.Т.Карпош“, Карпош & Даниела Радевска \\
\hline III & Љупка Науновска & ООУ „Гоце Делчев“, Свети Николе & Катерина Величкова \\
\hline III & Деница Темелкоска & ООУ „Гоце Делчев“, Прилеп & Кети Иваноска \\
\hline III & Дунимаглоска Викторија & ООУ „Блаже Конески“, Прилеп & Павлина Темелкоска \\
\hline \hline
\end{tabular}

Ова беше за првпат реализиран натпревар по хемија за ученици од основните училишта организиран од Сојузот на хемичарите и технолозите на Македонија со учество на Институтот за хемија при Природно-математичкиот факултет во Скопје. Оваа активност ќе продолжи и во следните години со цел развивање на интерес и мотивирање на најмладите за хемијата.

Марина Стојановска Институт за хемија, Природно-математички фракултет Скопје marinam@pmf.ukim.mk 